\title{
Effects of Inoculation by Bradyrhizobium japonicum Strains on Nodulation, Nitrogen Fixation, and Yield of Soybean (Glycine max L. Merill) Varieties on Nitisols of Bako, Western Ethiopia
}

\author{
Tamiru Solomon, Lalit Mohan Pant, and Tsige Angaw \\ Department of Natural Resource Management, College of Agriculture and Environmental Science, Haramaya University, \\ Oromia Regional State, East Hararghe, P.O. Box 20, Dire Dawa, Ethiopia
}

Correspondence should be addressed to Tamiru Solomon, tamirusolomon@yahoo.com

Received 4 May 2012; Accepted 4 July 2012

Academic Editors: T. E. Fenton and S. Thompson

Copyright ( $\odot 2012$ Tamiru Solomon et al. This is an open access article distributed under the Creative Commons Attribution License, which permits unrestricted use, distribution, and reproduction in any medium, provided the original work is properly cited.

A field experiment was conducted during the 2005/6 growing season to assess the effect of Bradyrhizobium japonicum strains on the performance of soybean varieties. The field experiment was conducted at Bako ATVET College, West Shoa, Ethiopia. Three varieties of soybean (Jalele, Cheri, and Ethio-Yugoslavia) and two strains of Bradyrhizobium japonicum (TAL 378 and TAL 379) along with one uninoculated treatment were laid out in a randomized complete block design with nine variety and strain combinations and three replications. Inoculated and uninoculated seeds of soybean were planted on prepared beds. All the nodulation parameters, namely, nodulation rating, nodule number per plant, nodule volume per plant, and nodule dry weight were significantly influenced by the main effect of Bradyrhizobium japonicum strains alone. The main effect of soybean variety did not affect these parameters significantly. The dry matter production and nitrogen uptake at midflowering were highly significantly $(P \leq 0.01)$ affected by the main effects of both variety and strain. The yield and the yield components such as number of pods per plant, number of seeds per pod, seed yield, thousand seed weight, above-ground dry biomass, and total nitrogen uptake were highly significantly $(P \leq 0.01)$ affected by inoculation of Bradyrhizobium strains alone. A yield increase of $53.2 \%$ was obtained due to inoculation of TAL 379 over the uninoculated control. The variety effect was also significant $(P \leq 0.01)$ on number of pods per plant, seed yield, thousand seed weight, harvest index, and total nitrogen uptake. Variety and Bradyrhizobium strain interaction was detected on number of nodules per plant and nodule dry weight.

\section{Introduction}

Nitrogen is one of the most abundant elements on earth. However, it is one of the most limiting factors of growth and production of crops. Nitrogen can be utilized when it is reduced to ammonia by nitrogen fixation. It can be reduced by chemical fixation through industrial production and/or biological fixation involving microorganisms. Even in the presence of such process called biological nitrogen fixation, nitrogen is one of the usually deficient plant nutrients in soils. Despite its abundance in the atmosphere as a gas, it cannot be utilized directly by plants. Most plants utilize nitrogen in its ionic forms ammonium $\left(\mathrm{NH}_{4}{ }^{+}\right)$and nitrate $\left(\mathrm{NO}_{3}{ }^{-}\right)$from soil [1].
The increasing cost of fertilizers and their impact on the environment have forced people to look for other possible sources of plant nutrients. In this regard, nitrogen fixation which is a process by which elemental atmospheric nitrogen is changed to organic forms by biological nitrogen fixation both by symbiotic and asymbiotic microorganisms in soil has drawn much attention. The symbiotic nitrogen fixation is used to maximum advantage in case of leguminous crops. There is no doubt that specificity exists between rhizobialstrain and the legume, and compatibility between the two is essential for successful nodulation. This necessitates using specific cultures for different legumes. When growing a new legume species on a soil, it is necessary that the appropriate rhizobial culture be applied [2]. 
Soils usually lack Bradyrhizobium japonicum strains unless soybean is grown on them for at least five or more years. Hiltbold et al. [3] reported that numbers of Bradyrhizobium japonicum in 52 Iowa fields were correlated with whether soybeans had been grown at the site within the previous 13 years. It is therefore important to inoculate seeds with relevant strains of bacteria before sowing especially if the crop is to be grown for the first time on the land. Inoculation responses are associated primarily with the first planting of a legume in soil having no prior history of the crop [4-6]. In any case, to get the maximum benefit out of inoculation there is a need to follow correct and careful inoculation procedures, and the inoculant should carry live and effective bacterial cells.

Cultivar variation affects levels of nitrogen fixation in many legume crop species, and in some crops particular combinations of strain and cultivar have been shown to be especially efficient at fixing nitrogen [7]. There were varying reports on the interaction between variety and strain in soybean. Thao et al. [8] found a significant interaction between variety and strain on different parameters whereas Munyinda et al. [9] reported a nonsignificant interaction. Therefore, the specific objectives of this research were to

Study the effects of inoculated Bradyrhizobium japonicum strains on nodulation and nitrogen fixation of soybean (Glycine max L. Merill) varieties and

Determine the main and interaction effects of Bradyrhizobium japonicum strains and soybean varieties on yield and yield-related parameters of soybean on Nitisols of Bako, Western Ethiopia.

\section{Materials and Methods}

2.1. The Experimental Site. The experiment was conducted on Nitisols of Bako ATVET College Campus Experimental field during the 2005-2006 growing season. Bako is a small town in West Shoa zone of Oromia region which is located at $09^{\circ} 06^{\prime}$ north latitude and $37^{\circ} 09^{\prime}$ east longitude. Its elevation is 1650 meters above sea level (masl). According to the climate data collected from 1998 to 2002, the total annual rainfall of the area ranges from 1040 to $1559 \mathrm{~mm}$. Mean annual maximum temperature is $31^{\circ} \mathrm{C}$ and the minimum being $11.2^{\circ} \mathrm{C}$. The mean relative humidity is $64 \%$. The mean soil temperature at the depth of $50 \mathrm{~cm}$ is $23.3^{\circ} \mathrm{C}$. The major soil types at Bako area are Nitisols according to the FAO/UNESCO or Alfisols according to USDA soil classification systems. These soils are well-drained reddish brown in color and slightly to moderately acidic in reaction with surface soil $\mathrm{pH}\left(\mathrm{H}_{2} \mathrm{O}\right)$ ranging from 5.3 to 6.5 [10].

2.2. Present Land Use. The Bako area is well known for its maize production. A number of improved maize varieties, well-known throughout the country, were released by the Bako Agricultural Research Center. It is characterized by mixed crop-livestock farming system, encompassed by the Gibe River and with abundant natural vegetation, and grass lands [11]. The major annual and perennial crops of the area include maize (Zea mays), sorghum (Sorghum bicolour), teff
(Eragrostis tef), noug (Guizotia abyssinica), hot pepper (Capsicum frutescence), haricot bean (Phaseolus vulgaris), sweet potato (Ipomoea batatas), mango (Mangifera indica), banana (Musa spp.), and sugarcane (Saccharum officinarum) [12]. Soybean had not been planted previously at the particular experimental site.

\subsection{Description and Sources of Experimental Treatments and} Materials. The study enhanced a factorial combination of two strains of Bradyrhizobium japonicum (TAL 378 and TAL 379) along with one uninoculated treatment and three varieties of soybean (Jalele, Cheri, and Ethio-Yugoslavia) arranged in a randomised complete block design with three replications. Peat carrier-based inoculants of two strains (TAL 378 and TAL 379) of Bradyrhizobium japonicum were obtained from the Soil Microbiology Laboratory of the National Soil Research Center (NSRC), Addis Ababa. Jalele and Cheri varieties of soybean that were released by the Bako Agricultural Research Center in 2003 were obtained from this Center. Ethio Yugoslavia was introduced and grown by an investor at Bako.

2.4. Land Preparation, Inoculation, and Planting. Land preparation was done following the conventional practice to make the field suitable for planting. Chemical fertilizer as DAP at $100 \mathrm{~kg} / \mathrm{ha}$ was applied at planting which supplied $18 \mathrm{~kg}$ nitrogen/ha as starter dose and $20.2 \mathrm{~kg}$ Phosphorous/ha. Then the land was leveled and divided into blocks and individual plots. The size of each plot was $3.2 \times 4 \mathrm{~m}$ $\left(12.8 \mathrm{~m}^{2}\right)$. The plots were kept $0.5 \mathrm{~m}$ apart with $1 \mathrm{~m}$ spacing between blocks. Canals were prepared around each plot making the plots beds.

Carrier-based inoculant of each strain, obtained from NSRC, was applied at the rate of $10 \mathrm{~g}$ inoculant $/ \mathrm{kg}$ seed [13]. In order to ensure that all the applied inoculum stick to the seed, the required quantity of inoculant was suspended in $1: 1$ ratio in $10 \%$ sugar solution. The thick slurry of the inoculant was gently mixed with dry seed so that all the seeds received a thin coating of the inoculant. All inoculations were done just before planting under shade to maintain the viability of bacterial cells. Seeds were allowed to air dry for a few minutes and were then sown at the required rate and spacing. Plots with uninoculated seeds were planted first to avoid contamination. The inoculated and uninoculated seeds of the varieties were then planted at a depth of $4 \mathrm{~cm}$ and at a spacing of $10 \mathrm{~cm}$ between plants and $40 \mathrm{~cm}$ between rows making 8 rows per plot. Seeds were immediately covered with soil after sowing to avoid death of cells due to the sun's radiation.

2.5. Nodulation and Nodule Data Collection. Five plants were sampled randomly from the second border rows of each plot at midflowering (50\% flowering). The whole plant was carefully uprooted using a spade so as to obtain intact roots and nodules for nodulation parameters and dry weight of plants. Uprooting was done by exposing the whole-root system to avoid loss of nodules. The adhering soil was removed by washing the roots with intact nodules gently with water over a metal sieve. The same five plants from each plot 
were used to rate nodulation and to record number of nodules per plant, nodule volume per plant, and nodule dry weight.

Out of the total number of plants uprooted from a treatment, the number of plants showing tap root nodulation (a), plants with nodules in secondary roots but close to tap root $(b)$, plants with scattered nodulation $(c)$, and plants without nodulation $(d)$ were counted. The nodulation rating for each treatment was then calculated according to the formula of the Nif Tal Project of the University of Hawaii [14] as follows:

$$
\text { Nodulation rating }=\frac{(a \times 10)+(b \times 5)+(c \times 1)+(d \times 0)}{\text { Total no. of plants }} .
$$

After calculation of nodulation rating, the number of nodules per plant was determined by counting the number of nodules from all the five uprooted plants per plot and then averaged as per plant. To determine nodule volume, the nodules of the above five plants of each plot were collected carefully and immersed in a $50 \mathrm{~mL}$ capacity plastic cylinder which was filled up to $30 \mathrm{~mL}$ with water. The volume of water displaced by the nodules obtained from the five plants was recorded, and the average was considered as nodule volume per plant. Finally, the nodules collected from the five plant samples from each plot were pooled, and their dry weight was determined by drying the nodules at $70^{\circ} \mathrm{C}$ to constant weight, and the dry weight was reported as mg/plant.

2.6. Crop Yield and Agronomic Data Collection. Five plants were sampled randomly at maturity from each plot, pods were counted for all the five plants, and the average value was reported as number of pods per plant. The number of seeds per pod was determined from 20 pods randomly sampled from the five sample plants, and the average was reported as number of seeds per pod. The number of plants per plot was recorded at harvesting from the central six rows, and the mean was computed and used for the analysis of final plant stand.

Soybean plants were harvested from each plot at physiological maturity leaving the border rows and $0.5 \mathrm{~m}$ row length on every end of each rows. Seed yield was obtained by adjusting the moisture level to $10 \%$ according to the formula indicated by Abebe [15] as follows and converted into kg/ha:

$$
\text { Adjusted yield }=\frac{100-\mathrm{MC}}{100-10} \times \text { unadjusted yield, }
$$

where MC is moisture content of soybean seeds at the time of measurement, and 10 is the standard moisture content of soybean seeds at harvest in percent.

The weights of thousand seeds randomly counted from the seeds of each plot maintaining the seed moisture content at $10 \%$ were reported as thousand seeds weight. Whole plants, including above-ground parts and roots after separating the nodules, sampled from each plot at midflowering were pooled together and oven dried at $70^{\circ} \mathrm{C}$ to constant weight. The average of five plants was reported as dry weight per plant.
After recording the seed yield, for each plot, five plants were taken randomly from the central rows and oven dried at $70^{\circ} \mathrm{C}$ to constant weight to determine above-ground dry matter yield. Finally, the total above-ground biomass yield was obtained by adding the seed yield and above-ground dry matter yield. Harvest index was calculated as a ratio of seed yield to above-ground biomass yield.

2.7. Nitrogen Uptake at Midflowering and Maturity. The plant samples taken at midflowering from each plot were oven dried at $70^{\circ} \mathrm{C}$ to a constant weight, ground to pass a $1 \mathrm{~mm}$ sieve, and analyzed for their nitrogen concentrations using the modified Kjeldahl method as described by Jackson [16]. Finally, nitrogen uptake was determined as the product of straw yield and the respective nitrogen content in the straw and reported as mg nitrogen/plant.

Representative seed and straw samples were taken separately from each replication and composited treatment wise. Materials were separately air dried and then oven dried at $70^{\circ} \mathrm{C}$ to a constant weight, ground to pass a $1 \mathrm{~mm}$ sieve and were saved for laboratory analysis of seed and straw nitrogen concentrations. The nitrogen in the plant parts was determined by the modified Kjeldahl method as described by Jackson [16]. Seed and straw nitrogen uptakes were determined as the product of seed and straw yield and the respective nitrogen content in the seed and straw, respectively. Total nitrogen uptake was calculated as the summation of seed and straw nitrogen uptake. The inoculated and uninoculated treatments were compared by comparing the nitrogen uptakes by plants in both cases.

2.8. Statistical Analysis. The data were subjected to analysis of variance following the standard procedure given by $\mathrm{K}$. A. Gomez and A. A. Gomez [17] using MSTAT computer software. Square root transformation was used to make the assumptions of normality and additivity for nodular parameters (NR, NNP, NVP, and NDW) data. Mean separation was done by the Duncan's Multiple Range Test method.

\section{Results}

3.1. Selected Physicochemical Properties of Soil. Soil analysis of the experimental field has shown that the soil was moderately acidic in reaction $(\mathrm{pH}=5.5)$ and sandy clay loam in texture (Table 1 ). The cation exchange capacity (CEC) of the soil was found to be $15.60 \mathrm{Cmol}(+) / \mathrm{kg}$ which is low according to Tisdale et al. [18]. This low CEC may be attributed to the higher percentage $(47 \%)$ of sand in the soil which is low in CEC and also the acidic nature of the soil. The total nitrogen and organic carbon contents of the soil before sowing were found to be $0.140 \%$ and $1.88 \%$, respectively, whereas available phosphorous content was $14.82 \mathrm{ppm}$ (Table 1).

\subsection{Nodulation Parameters}

3.2.1. Nodulation Rating. Uninoculated control did not show any nodule indicating the absence of native rhizobial population specific to soybean. Soybean varieties, irrespective of rhizobial strain inoculation, did not vary significantly in 
TABLE 1: Surface $(0-30 \mathrm{~cm})$ soil physical and chemical properties of the experimental site.

\begin{tabular}{lccccccccc}
\hline \multicolumn{2}{c}{ Particle size distribution (\%) } & Textural class & $\begin{array}{c}\mathrm{pH}(1: 2.5 \\
\left.\mathrm{H}_{2} \mathrm{O}\right)\end{array}$ & OC $(\%)$ & TN $(\%)$ & AP $(\mathrm{ppm})$ & $\begin{array}{c}\mathrm{CEC}(\mathrm{Cmol} \\
(+) / \mathrm{kg})\end{array}$ \\
Sand & Silt & Clay & & & & & & PBS \\
\hline 47 & 20 & 33 & SCL & 5.5 & 1.88 & 0.14 & 14.82 & 15.60 \\
\hline
\end{tabular}

SCL: sandy clay loam; OC: organic carbon; TN: total nitrogen; AP: available phosphorous; CEC: cation exchange capacity; PBS: percent base saturation.

TABLE 2: Main effects of soybean varieties and B. japonicum strains on nodulation rating, number of nodules per plant, nodule volume per plant, and nodule dry weight.

\begin{tabular}{|c|c|c|c|c|}
\hline Treatment & Nodulation rating & $\begin{array}{c}\text { Number of nodules } \\
\text { (no./plant) }\end{array}$ & $\begin{array}{c}\text { Nodule volume } \\
(\mathrm{mL} / \text { plant })\end{array}$ & $\begin{array}{c}\text { Nodule dry weight } \\
(\mathrm{mg} / \text { plant })\end{array}$ \\
\hline & \multicolumn{4}{|c|}{ Variety } \\
\hline Jalele & 2.38 & 4.36 & 0.29 & 68.89 \\
\hline Cheri & 2.47 & 4.49 & 0.29 & 64.44 \\
\hline \multirow[t]{2}{*}{ Ethio-Yugoslavia } & 2.73 & 3.31 & 0.24 & 50.89 \\
\hline & \multicolumn{4}{|c|}{ Strain } \\
\hline Uninoculated & $0.00^{\mathrm{b}}$ & $0.00^{\mathrm{b}}$ & $0.00^{\mathrm{b}}$ & $0.00^{\mathrm{b}}$ \\
\hline TAL 378 & $0.78^{\mathrm{b}}$ & $0.13^{\mathrm{b}}$ & $0.06^{\mathrm{b}}$ & $4.22^{\mathrm{b}}$ \\
\hline \multirow[t]{2}{*}{ TAL 379} & $6.80^{\mathrm{a}}$ & $12.02^{\mathrm{a}}$ & $0.77^{\mathrm{a}}$ & $180.00^{\mathrm{a}}$ \\
\hline & \multicolumn{4}{|c|}{ Significance } \\
\hline Variety & NS & NS & NS & NS \\
\hline Strain & $* *$ & $* *$ & $* *$ & $* *$ \\
\hline Variety $\times$ strain & NS & $*$ & NS & $*$ \\
\hline $\mathrm{CV}(\%)$ & 22.19 & 12.66 & 6.62 & 25.18 \\
\hline
\end{tabular}

NS, ${ }^{*},{ }^{*}$ : nonsignificant or significant at $P<0.05$ or 0.01 , respectively. Means within a column followed by the same letter(s) are not significantly different.

relation to nodulation rating. Nodulation rating was not significantly affected by the interaction effect of soybean variety and rhizobial strain (Table 2). On the other hand, inoculation of soybean seeds with Bradyrhizobium japonicum strains has resulted in a highly significant $(P<0.01)$ increase in nodulation rating as compared to the control (Table 2). The strain TAL 379 produced significantly higher nodulation rating value as compared to TAL 378 and the uninoculated control. The strain TAL 378 produced insignificant number of nodules in all the varieties, and it was statistically equal with the uninoculated control in relation to nodulation rating.

3.2.2. Number of Nodules per Plant. As it is evident from the data presented in Tables 2 and 3, the number of nodules per plant was not affected significantly by the main effect of soybean variety. However, Danso et al. [19] reported varietal differences in terms of nodule numbers due to inoculation of different rhizobial strains. On the other hand, the main effect of strain has shown a highly significant $(P \leq 0.01)$ influence on the number of nodules per plant (Table 2). This is in agreement with observations of $\mathrm{Wu}$ and Arima [20] in Chinese milk vetch. In the current study, the strain TAL 379 produced significantly higher number of nodules than TAL 378 and the uninoculated control. The uninoculated control did not produce any nodule at all, and TAL 378 was statistically at par with uninoculated control. This is an indication that native strains of Bradyrhizobium japonicum
TABLE 3: The interaction effect of soybean varieties and B. japonicum strains on nodule number and nodule dry weight per plant.

\begin{tabular}{lcc}
\hline Treatments & $\begin{array}{c}\text { Number of nodules } \\
\text { (no./plant) }\end{array}$ & $\begin{array}{c}\text { Nodule dry weight } \\
(\mathrm{mg} / \text { plant })\end{array}$ \\
\hline \multicolumn{3}{c}{ Variety } \\
\hline Jalele (uninoculated) & $0.00^{\mathrm{c}}$ & $0.00^{\mathrm{d}}$ \\
Cheri (uninoculated) & $0.00^{\mathrm{c}}$ & $0.00^{\mathrm{d}}$ \\
ET-Y (uninoculated) & $0.00^{\mathrm{c}}$ & $0.00^{\mathrm{d}}$ \\
\hline \multicolumn{3}{c}{ Variety $\times$ strain } \\
\hline TAL 378 + Jalele & $0.07^{\mathrm{c}}$ & $0.00^{\mathrm{d}}$ \\
TAL 379 + Jalele & $13.00^{\mathrm{a}}$ & $206.67^{\mathrm{a}}$ \\
TAL 378 + Cheri & $0.00^{\mathrm{c}}$ & $0.00^{\mathrm{d}}$ \\
TAL 379 + Cheri & $13.47^{\mathrm{a}}$ & $193.33^{\mathrm{ab}}$ \\
TAL 378 + ET-Y & $0.33^{\mathrm{c}}$ & $12.67^{\mathrm{c}}$ \\
TAL 379 + ET-Y & $9.60^{\mathrm{b}}$ & $140.00^{\mathrm{b}}$ \\
\hline
\end{tabular}

Means within a column followed by the same letter(s) are not significantly different.

bacteria that could form symbiotic relation with soybean are absent in the soils of Bako.

The interaction between soybean varieties and rhizobial strains was found significant in relation to number of nodules (Table 3). The interaction of soybean variety Cheri with strain TAL 379 resulted in the highest number of nodules (13.47 nodules/plant) followed by inoculation with TAL 379 on variety Jalele (13.0 nodules/plant). However, both were 
statistically at par. The interaction effect of B. japonicum strain (TAL 378) with all the soybean varieties was significantly lower than TAL 379 and was found at par with uninoculated control in relation to number of nodules.

3.2.3. Nodule Volume per Plant. Analysis of variance has shown that the nodule volume per plant was not affected significantly by the main effect of the soybean varieties. However, it was significantly $(P \leq 0.01)$ affected by the main effect of B. japonicum strain. Strain TAL 379 recorded significantly higher nodule volume compared to TAL 378 and the uninoculated control. The interaction of soybean varieties with rhizobial strains was nonsignificant in relation to nodule volume (Table 2).

3.2.4. Nodule Dry Weight. The dry weight of nodules was not affected significantly $(P>0.05)$ by the main effect of soybean variety (Table 2). This is in line with findings of Gebrekidan [21] on chickpea grown at two locations. On the contrary, the main effect of rhizobial strain affected the nodule dry weight significantly $(P \leq 0.01)$.

Nodule dry weight was significantly $(P \leq 0.05)$ affected by the interaction of soybean variety and rhizobial strain (Table 3 ). Soybean variety Jalele produced zsignificantly higher nodule dry weight $(206.67 \mathrm{mg} /$ plant $)$ when inoculated with B. japonicum strain TAL 379 followed by variety Cheri $(193.33 \mathrm{mg} /$ plant $)$ with the same rhizobial strain. This is in agreement with the report of Lindermann and Ham [22] who observed that nodule dry weight was significantly dependent on $B$. japonicum strain and soybean variety interaction.

\subsection{Dry Matter Production and Nitrogen Uptake}

3.3.1. Dry Matter Production. The dry matter production at midflowering was significantly $(P \leq 0.01)$ influenced by the main effect of soybean varieties. Soybean variety EthioYugoslavia produced significantly higher amount of dry matter $(23.75 \mathrm{~g} /$ plant $)$ than Jalele and Cheri which recorded 19.03 and $17.22 \mathrm{~g} /$ plant dry matter, respectively. However, the varieties Jalele and Cheri were statistically at par in terms of dry matter production (Table 4). Lindermann and Ham [22] have also reported significant varietal differences in soybean in relation to dry matter.

The main effect of inoculation of rhizobial strains also showed significant $(P \leq 0.01)$ difference with respect to dry matter production. Irrespective of the soybean variety, inoculation of Bradyrhizobium japonicum strain TAL 379 resulted in highest dry matter production. Vasilas and Ham [23] and Sparrow et al. [24] have also reported similar findings on several legumes. On the other hand, the variety and strain interaction was found to be nonsignificant in relation to dry matter yield.

3.3.2. Nitrogen Uptake. The main and interaction effects on nitrogen uptake due to soybean varieties and rhizobial strains are presented in Table 4 . The nitrogen uptake by soybean at midflowering was significantly $(P \leq 0.01)$ influenced by the main effect of variety. The nitrogen uptake at midflowering
TABLE 4: Main effects of soybean varieties and B. japonicum strains on dry matter production and nitrogen uptake at midflowering.

\begin{tabular}{lcc}
\hline Treatment & Dry matter (g/plant) & $\begin{array}{c}\text { Nitrogen uptake } \\
(\mathrm{mg} / \text { plant })\end{array}$ \\
\hline \multicolumn{3}{c}{ Variety } \\
\hline Jalele & \multicolumn{3}{c}{$654.91^{\mathrm{b}}$} \\
Cheri & $17.22^{\mathrm{b}}$ & $644.25^{\mathrm{b}}$ \\
Ethio-Yugoslavia & $23.75^{\mathrm{a}}$ & $872.22^{\mathrm{a}}$ \\
\hline \multicolumn{3}{c}{ Strain } \\
\hline Uninoculated & $16.78^{\mathrm{b}}$ & $555.62^{\mathrm{b}}$ \\
TAL 378 & $17.10^{\mathrm{b}}$ & $578.90^{\mathrm{b}}$ \\
TAL 379 & $26.12^{\mathrm{a}}$ & $1036.86^{\mathrm{a}}$ \\
\hline \multicolumn{3}{c}{ Significance } \\
\hline Variety & $* *$ & $* *$ \\
Strain & $* *$ & $\mathrm{NS}$ \\
Variety $\times$ strain & $\mathrm{NS}$ & 15.35 \\
\hline CV $(\%)$ & 13.44 &
\end{tabular}

NS, **: nonsignificant or significant at $P<0.01$, respectively. Means within a column followed by the same letter(s) are not significantly different.

stage was also affected significantly $(P \leq 0.01)$ by the main effect of rhizobial strain. The interaction of variety with strain had a nonsignificant influence on the nitrogen uptake by soybean at midflowering (Table 4 ).

\subsubsection{Yield and Yield-Related Parameters}

Number of Pods per Plant. The main effect of soybean varieties alone was significant in relation to number of pods per plant. EthioYugoslavia recorded significantly higher number of pods as compared to Jalele although it was statistically at par with Cheri. The number of pods per plant was also significantly $(P \leq 0.01)$ affected by the main effect of Bradyrhizobial strains. The inoculation of strain TAL 379 resulted in significantly higher number of pods per plant whereas effect of inoculation of TAL 378 and the control was statistically at par. The inoculation of TAL 379 resulted in $65.01 \%$ more number of pods per plant as compared to the uninoculated control. Interaction of variety and strain resulted in a nonsignificant influence on the number of pods per plant (Table 5).

3.3.4. Number of Seeds per Pod. Although the number of seeds per pod was not significantly different among the varieties, it was affected significantly $(P \leq 0.01)$ due to inoculation of rhizobial strains. The inoculation of TAL 379 resulted in significantly higher number of seeds per pod than TAL 378 and the uninoculated control (Table 5). The interaction of variety and strain has shown a nonsignificant influence on the number of seeds per pod (Table 5).

3.3.5. Final Plant Stand. The summarized results for the final plant stand are presented in Table 5. The results indicated that final plant stand was not significantly affected by the main effects of both variety and strain. The interaction effect 
TABLE 5: Main effects of soybean varieties and B. japonicum strains on number of pods per plant, number of seeds per pod, final plant stand count, seed yield, and thousand seed weight.

\begin{tabular}{lccccc}
\hline Treatment & NPP (Nr.) & $\begin{array}{c}\text { NSP } \\
(\mathrm{Nr} .)\end{array}$ & $\begin{array}{c}\text { FPS } \\
(\mathrm{Nr} .)\end{array}$ & $\begin{array}{c}\text { SY } \\
(\mathrm{kg} / \mathrm{ha})\end{array}$ & $\begin{array}{c}\text { TSW } \\
(\mathrm{g})\end{array}$ \\
\hline Jalele & $77.36^{\mathrm{b}}$ & 2.21 & 162.44 & $2560.19^{\mathrm{b}}$ & $212.81^{\mathrm{a}}$ \\
Cheri & $100.62^{\mathrm{a}}$ & 2.07 & 161.56 & $3416.67^{\mathrm{a}}$ & $204.07^{\mathrm{a}}$ \\
Ethio-Yugoslavia & $103.82^{\mathrm{a}}$ & 2.18 & 157.89 & $3044.75^{\mathrm{ab}}$ & $181.41^{\mathrm{b}}$ \\
\hline \multicolumn{5}{c}{ Strain } \\
\hline Uninoculated & $75.71^{\mathrm{b}}$ & $2.09^{\mathrm{b}}$ & 161.33 & $2580.25^{\mathrm{b}}$ & $190.54^{\mathrm{b}}$ \\
TAL 378 & $81.16^{\mathrm{b}}$ & $2.07^{\mathrm{b}}$ & 159.67 & $2487.65^{\mathrm{b}}$ & $191.36^{\mathrm{b}}$ \\
TAL 379 & $124.93^{\mathrm{a}}$ & $2.30^{\mathrm{a}}$ & 160.89 & $3953.71^{\mathrm{a}}$ & $216.39^{\mathrm{a}}$ \\
\hline \multicolumn{5}{c}{ Significance } \\
\hline Variety & $* *$ & $\mathrm{NS}$ & $\mathrm{NS}$ & $* *$ \\
Strain & $* *$ & $* *$ & $\mathrm{NS}$ & $* *$ & $* *$ \\
Variety $\times$ Strain & $\mathrm{NS}$ & $\mathrm{NS}$ & $\mathrm{NS}$ & $\mathrm{NS}$ & $\mathrm{NS}$ \\
\hline CV $(\%)$ & 15.19 & 6.01 & 2.84 & 15.65 & 7.00 \\
\hline
\end{tabular}

NS, **: nonsignificant or significant at $P<0.01$, respectively. Means within a column followed by the same letter(s) are not significantly different. NPP: number of pods per plant, NSP: number of seeds per pod, FPS: final plant stand, SY: seed yield, TSW: thousand seed weight, Nr: number.

TABLE 6: Main effects of soybean varieties and B. japonicum strains on the above-ground dry biomass yield, harvest index, and total nitrogen uptake.

\begin{tabular}{lccc}
\hline Treatment & BY (ton/ha) & HI & $\begin{array}{c}\text { TNU } \\
(\mathrm{mg} / \text { plant })\end{array}$ \\
\hline Jalele & \multicolumn{3}{c}{ Variety } \\
Cheri & 12.44 & $0.204^{\mathrm{b}}$ & $1783.71^{\mathrm{b}}$ \\
Ethio-Yugoslavia & 12.64 & $0.268^{\mathrm{a}}$ & $2106.29^{\mathrm{a}}$ \\
& 11.68 & $0.262^{\mathrm{a}}$ & $2055.27^{\mathrm{ab}}$ \\
\hline Uninoculated & $10.48^{\mathrm{b}}$ & Strain \\
TAL 378 & $10.75^{\mathrm{b}}$ & 0.248 \\
TAL 379 & $15.53^{\mathrm{a}}$ & 0.230 & $1580.20^{\mathrm{b}}$ \\
\hline \multicolumn{3}{c}{$1664.96^{\mathrm{b}}$} \\
Variety & Significance & $2700.12^{\mathrm{a}}$ \\
Strain & $\mathrm{NS}$ & $* *$ & $* *$ \\
Variety $\times$ strain & $\mathrm{NS}$ & $\mathrm{NS}$ & $* *$ \\
CV $(\%)$ & 10.22 & $\mathrm{NS}$ & $\mathrm{NS}$ \\
\hline
\end{tabular}

NS, ${ }^{* *}$ : nonsignificant or significant at $P<0.01$, respectively. Means within a column followed by the same letter(s) are not significantly different. BY: above-ground dry biomass yield, HI: harvest index, TNU: total nitrogen uptake at maturity.

of variety and strain did not show a significant influence on the final stand count of soybean.

3.3.6. Seed Yield. Seed yield was affected significantly $(P \leq$ 0.01 ) by the main effects of both soybean variety and rhizobial strain (Table 5). The higher seed yield by Cheri may be attributed to the larger number of pods per plant recorded by this variety. EthioYugoslavia on the other hand did not respond differently from either Jalele or Cheri (Table 5). A significant effect of varieties alone on seed yield of soybean was also found by Danso et al. [19]. An increase of 53.2\% seed yield was realized due to inoculation of TAL 379 as compared to the uninoculated control. Similar increases in seed yield have been recorded by a number of researchers $[23,25-28]$. The analysis of variance has indicated that variety and strain had no interaction effect on the seed yield.

3.3.7. Thousand Seed Weight. Thousand seed weight was found to be affected significantly $(P \leq 0.01)$ by the main effects of variety as well as the rhizobial strain. The interaction between soybean variety and $B$. japonicum strain was found nonsignificant in relation to thousand seed weight (Table 5).

3.3.8. Above-Ground Dry Biomass Yield. The main effect of varieties did not show significant effect on the above-ground dry biomass yield (Table 6). However, it was affected significantly $(P \leq 0.01)$ by the main effect of rhizobial strain. The inoculation of strain TAL 379 produced significantly more dry biomass yield $(15.53 \mathrm{t} / \mathrm{ha})$ as compared to TAL $378(10.75 \mathrm{t} / \mathrm{ha})$ and the uninoculated control (10.48 t/ha). An increase in the above-ground dry biomass was observed because rhizobial inoculation is known to increase the yields of several legumes by way of increasing the nodulation and the biomass of root and shoot [29]. In the present study, the variety-strain interaction showed a nonsignificant response on the above-ground dry biomass yield (Table 6).

3.3.9. Harvest Index. Harvest index was observed to be significantly $(P \leq 0.01)$ affected by the main effect of variety but not by the main effect of strain and the interaction effect of variety and strain (Table 6).

3.3.10. Total Nitrogen Uptake. The total nitrogen uptake by soybean plants at maturity was significantly $(P \leq 0.01)$ influenced by the main effect of variety. Senaratne et al. [30] and Danso et al. [19] also obtained a difference in total $\mathrm{N}$ between different soybean varieties. The total nitrogen uptake, irrespective of the soybean variety, was also affected by the inoculation of rhizobial strain alone. The inoculation of B. japonicum strain TAL 379 resulted in the maximum nitrogen uptake (2700.12 $\mathrm{mg} / \mathrm{plant})$ at maturity which was significantly higher than TAL 378 and uninoculated control (Table 6).

\section{Discussion}

Successful nodulation of leguminous crops by Rhizobium largely depends on the presence of a specific and compatible strain in soil for a particular legume. Soybean is a relatively new crop to Ethiopian farmers. Large-scale production of soybean is lacking in the study area. The crop was recently introduced in Bako area which is mainly limited to the Agricultural Research Center and few surrounding farmers. It had not been planted previously at the particular experimental site. Therefore, a field study was conducted in 2005-2006 growing season to assess the effects of two exotic strains (TAL 378 and TAL 379) of Bradyrhizobium japonicum on three varieties of soybean (Jalele, Cheri, and EthioYugoslavia) in relation to nodulation, nitrogen fixation, and yield. 
The total nitrogen value is in the low range of nitrogen content as per the criteria developed by Landon [31] for tropical soils whereas organic carbon content is moderate. The available $\mathrm{P}$ content of $14.82 \mathrm{ppm}$ lies in the high range according to Olsen P sufficiency test [18].

It seemed apparent from the responses obtained that the moderately acidic soil $\mathrm{pH}$ did not pose major problems on the bacterial strains, the soybean plant, and their association. Although the presence of high amount of total nitrogen in the rhizosphere is known to exert an adverse effect on the nodule nitrogen fixation of legumes [20], the total nitrogen content of the experimental field was found to be low. The low CEC of the soils of the experimental field may have effects on the performances of the soybean varieties to some extent.

Legumes have a high internal phosphorous requirement for their symbiotic nitrogen fixation. Singleton et al. [32] reported that, in addition to the nodule formation, deficiency of phosphorous in legumes also markedly affects the development of effective nodules and the nodule leghaemoglobin content. It is therefore suggested that the presence of high amount of available phosphorous in soils as in the soils of the experimental field may be beneficial to nodule nitrogen fixation through the prevention of the decrease of the phosphorous concentration in the plants at the later growth stage.

The inability of TAL 378 to produce nodules on soybean roots could be attributed to incompatibility of this strain with soybean varieties used in the present study. Kuykendall et al. [26] reported that soybean plants inoculated with strain TA-11 NOD ${ }^{+}$were significantly better nodulated than those inoculated with strain I-110 ARS. Danso et al. [19] also observed that Nitragin inoculant induced production of more nodules than strain D in soybean.

\section{Conclusion}

The results of the present study have indicated that it is important to promote the appropriate use of biofertilizers through national fertilizer programs. Efforts should be made, wherever possible, to introduce inoculation technology to the farming community. More research based on standard methods needs to be undertaken to assess the contribution of nitrogen-fixing plants to the overall nitrogen budget. The use of rhizobial inoculants is at its infancy in Ethiopia, and so far it is not one of the research priorities of Agricultural Research Institutions in the country. Rhizobial inoculants are not locally available, and farmers are not aware about this new technology. Therefore, more efforts need to be done to popularize this cheap and ecofriendly technology among resource poor farming community of the nation. For an alternative use, TAL 379 can be recommended for soybean inoculum production.

\section{Acknowledgments}

The funding for this study was provided by the Ministry of Agricultural and Rural Development. The authors thank all those who gave us constructive ideas in shaping this manuscript. However, only the authors did participate in the conduction of the study, data collection and interpretation, and article preparation.

\section{References}

[1] J. Rigaud, "Comparison of the efficiency of nitrate and nitrogen fixation in crop yield," in Nitrogen and Carbon Metabolism, J. D. Bewly, Ed., pp. 8-46, Nijhoff, Junk, The Hague, The Netherlands, 1981.

[2] R. Prasad and J. F. Power, Soil Fertility Management For Sustainable Agriculture, CRC Press, Boca Raton, Fla, USA, 1997.

[3] A. E. Hiltbold, R. M. Patterson, and R. B. Reed, "Soil populations of Rhizobium japonicum in a cotton-corn-soybean rotation," Soil Science Society of America Journal, vol. 49, no. 2, pp. 343-348, 1985.

[4] J. Brockwell, R. A. Holliday, D. M. Daoud, and L. A. Materon, "Symbiotic characteristics of a Rhizobium-specific annual medic, Medicago rigidula (L.) All," Soil Biology and Biochemistry, vol. 20, no. 5, pp. 593-600, 1988.

[5] J. Brockwell, R. J. Roughley, and D. F. Herridge, "Population dynamics of Rhizobium japonicum strains used to inoculate three successive crops of soybean," Australian Journal of Agricultural Research, vol. 38, no. 1, pp. 61-74, 1987.

[6] D. F. Herridge, R. J. Roughley, and J. Brockwell, "Low survival of Rhizobium japonicum inoculant leads to reduced nodulation, nitrogen fixation and yield of soybean in the current crop but not in the subsequent crop," Australian Journal of Agricultural Research, vol. 38, pp. 75-782, 1987.

[7] P. H. Graham, "Nitrogen transformations," in Hand Book of Soil Science, M. E. Summer, Ed., p. C-141, CRC Press, London, UK, 2000.

[8] T. Y. Thao, P. W. Singleton, and D. Herridge, "Inoculation responses of soybean and liquid inoculants as an alternative to peat-based inoculants," in Proceedings of the ACIAR Proceedings 109e on Inoculants and Nitrogen Fixation of Legumes in Vietnam, pp. 67-74, Oil Plant Institute of Vietnam, 2002.

[9] K. Munyinda, R. E. Karamanos, J. O. Legg, and S. Sanogho, "Nitrogen fixation by soybeans (Glycine max L.) in Zambia," Plant and Soil, vol. 109, no. 1, pp. 57-63, 1988.

[10] W. Negassa, Assessment of important physicochemical properties of dystric udalf (dystric Nitosols) under different management systems in Bako area, Western Ethiopia [M.S. thesis], School of Graduate Studies of Alemaya University, 2001.

[11] T. Abera, Effects of nitrogen, phosphorous, farmyard manure and population of climbing bean on the performance of maize (Zea mays L.) climbing bean (Phaseolus vulgaris L.) intercropping system in alfisols of Bako [M.S. thesis], School of Graduate Studies of Alemaya University, 2003.

[12] A. Negassa, A. Gemeda, T. Kumsa, and G. Gedeno, "Agroecological and socioeconomical circumstances of farmers in east Wollega zone of Oromiya region," Research Report No. 32, Institute of Agricultural Research, Addis Ababa, Ethiopia, 1997.

[13] W. A. Rice, G. W. Clayton, N. Z. Lupwayi, and P. E. Olsen, "Evaluation of coated seeds as a Rhizobium delivery system for field pea," Canadian Journal of Plant Science, vol. 81, no. 2, pp. 247-253, 2001.

[14] Nif Tal, ,Legume Inoculation Trials Procedures, Nif Tal Project, University of Hawaii, Honolulu, Hawaii, USA, 1979.

[15] B. Abebe, Agricultural Field Experiment Management Manual Part III, Institute of Agricultural Research, Addis Ababa, Ethiopia, 1979. 
[16] M. C. Jackson, Soil Chemical Analysis, Prentice Hall, Englewood Cliffs, NJ, USA, 1975.

[17] K. A. Gomez and A. A. Gomez, Statistical Procedure for Agricultural Research, John Wiley \& Sons, New York, NY, USA, 2nd edition, 1984

[18] S. L. Tisdale, J. D. Nelson, R. Beaton, and J. L. Havlin, Soil Fertility and Fertilizers, Prentice Hall, New Delhi, India, 7th edition, 2002.

[19] S. K. A. Danso, C. Hera, and C. Douka, "Nitrogen fixation in soybean as influenced by cultivar and Rhizobium strain," Plant and Soil, vol. 99, no. 1, pp. 163-174, 1987.

[20] J. Wu and Y. Arima, "Effect of Rhizobium inoculation and application of N,P,K fertilizer on the growth and nitrogen fixation of field-grown Chinese milk vetch," Soil Science and Plant Nutrition, vol. 38, no. 1, pp. 75-84, 1992.

[21] D. Gebrekidan, Effect of planting date and seed bed types on yield and yield components of chickpea (Cicer arietinum L.) varieties in vertisols of Tigray region [M.S. thesis], School of Graduate Studies of Alemaya University, 2003.

[22] W. C. Lindermann and G. E. Ham, "Soybean plant growth, nodulation, and nitrogen fixation as affected by root temperature," Soil Science Society of America Journal, vol. 43, no. 6, pp. 1134-1140, 1979.

[23] B. L. Vasilas and G. E. Ham, "Nitrogen fixation in soybeans: an evaluation of measurement techniques," Agronomy Journal, vol. 76, no. 5, pp. 759-764, 1984.

[24] S. D. Sparrow, V. L. Cochran, and E. B. Sparrow, "Dinitrogen fixation by seven legume crops in Alaska," Agronomy Journal, vol. 87, no. 1, pp. 34-41, 1995.

[25] L. J. Abendroth and R. W. Elmore, Soybean Inoculation: Applying the Facts to Your Fields, Part two, University of Nebraska, 2006, http://www.ianrpubs.unl.edu/epublic/live/ g1622/build/g1622.pdf.

[26] L. D. Kuykendall, F. M. Hashem, and W. J. Hunter, "Enhanced competitiveness of a bradyrhizobium japonicum mutant strain improved for nodulation and nitrogen fixation," Plant and Soil, vol. 186, no. 1, pp. 121-125, 1996.

[27] D. K. Pahalwan and R. S. Tripathi, "Nodulation, accumulation and redistribution of nitrogen in soybean (Glycine max (L.) Merrill) as influenced by seed inoculation and scheduling of irrigation," Plant and Soil, vol. 81, no. 2, pp. 235-246, 1984.

[28] M. L. Vitosh, "Soybean inoculation in Michigan," Michigan State University, Department of Crop and Soil Sciences, Ann Arbor, Mich, USA, 1997, http://www.michigansoybean.org/.

[29] N. S. SubbaRao, K. V. B. R. Tilak, and C. S. Singh, "Dual inoculation with Rhizobium sp. and Glomus fasciculatum enhances nodulation, yield and nitrogen fixation in chickpea (Cicer arietinum Linn.)," Plant and Soil, vol. 95, no. 3, pp. 351-359, 1986.

[30] R. Senaratne, C. Amornpimol, and G. Hardarson, "Effect of combined nitrogen on nitrogen fixation of soybean (Glycine $\max$ L. Merill.) as affected by cultivar and rhizobial strain," Plant and Soil, vol. 103, no. 1, pp. 45-50, 1987.

[31] J. R. Landon, Booker Tropical Soil Manual. A Hand Book for Soil Survey and Agricultural Land Evaluation in the Tropics and Subtropics, Booker Agricultural International limited, Bath, UK, 1984.

[32] P. W. Singleton, H. M. Abdelmagid, and J. W. Tavares, "Effect of phosphorus on the effectiveness of strains of Rhizobium japonicum," Soil Science Society of America Journal, vol. 49, no. 3, pp. 613-616, 1985. 


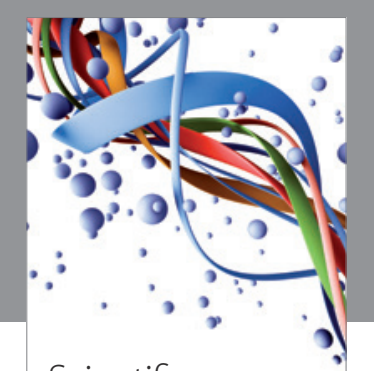

Scientifica
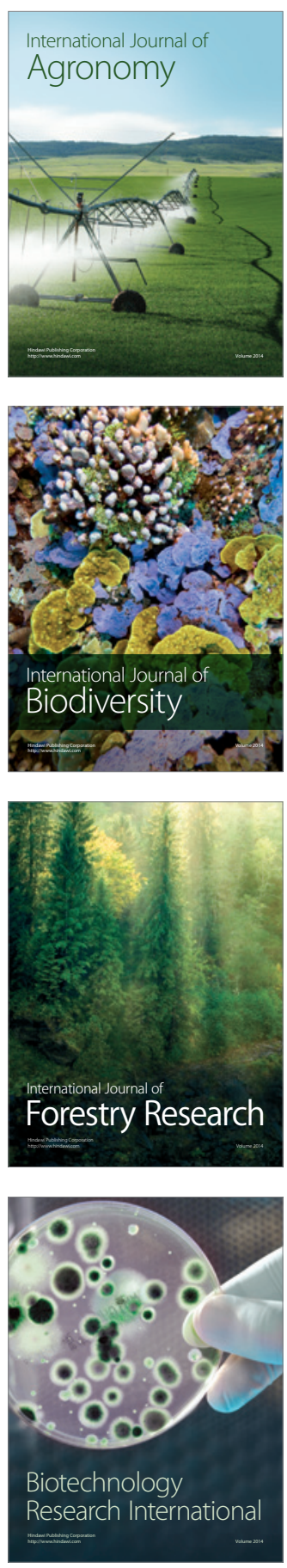
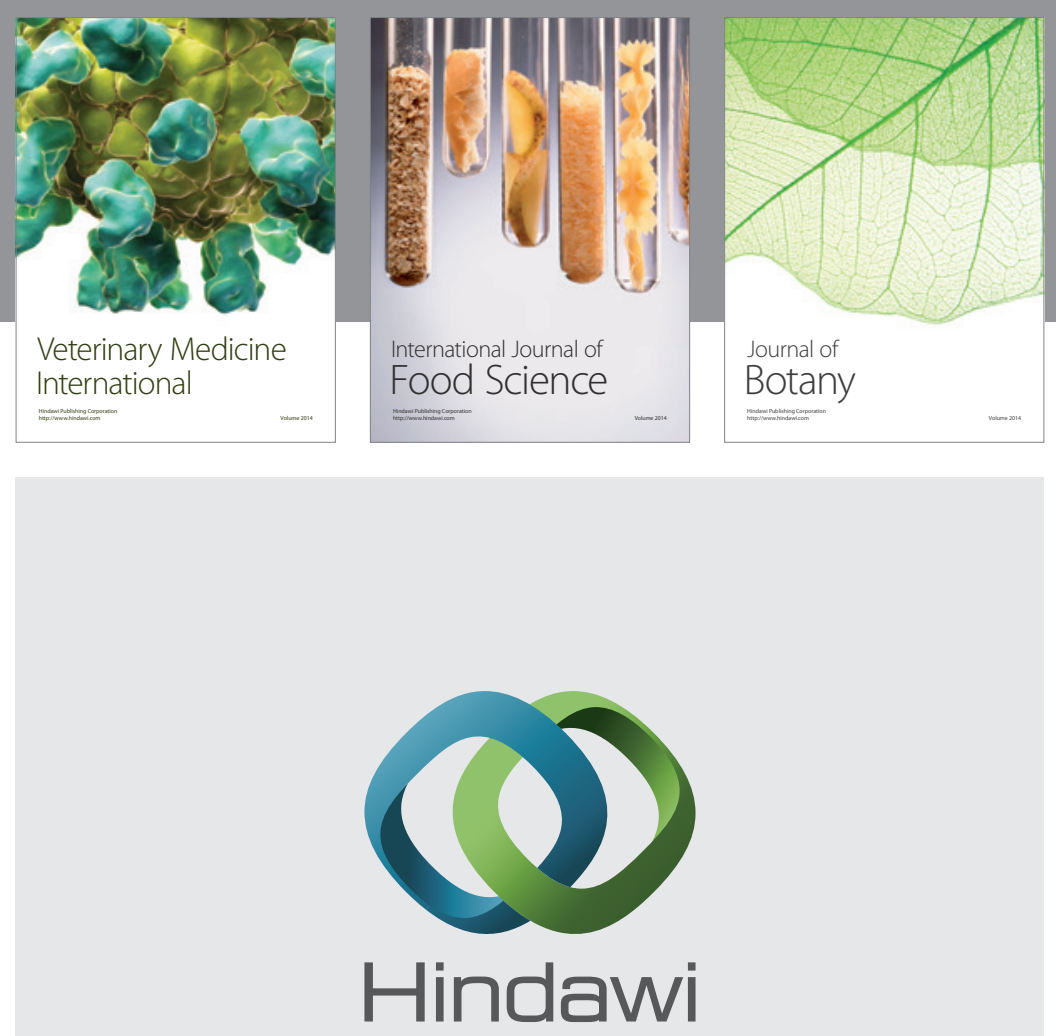

Submit your manuscripts at

http://www.hindawi.com
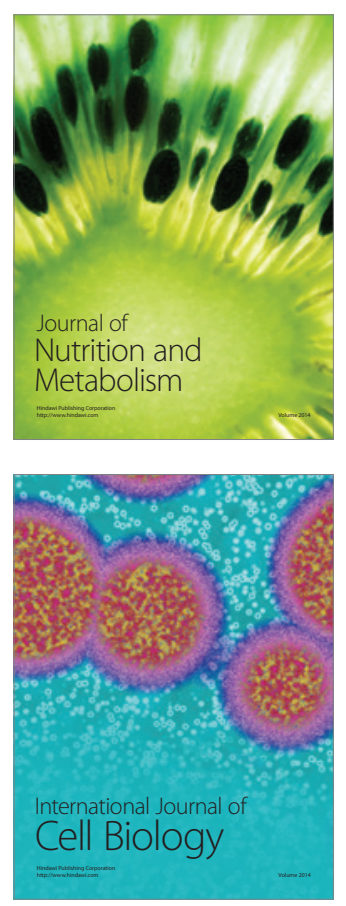
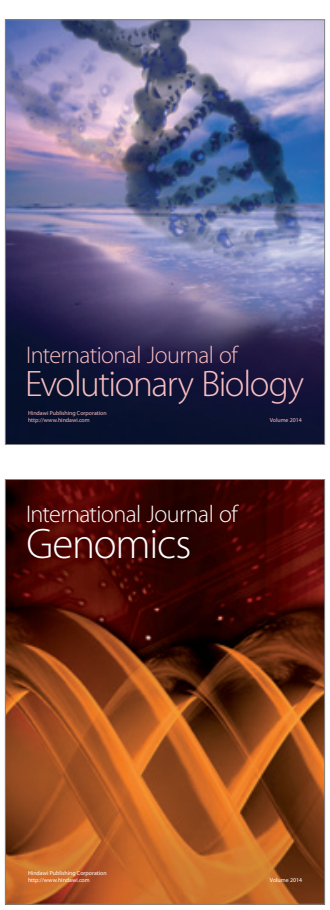
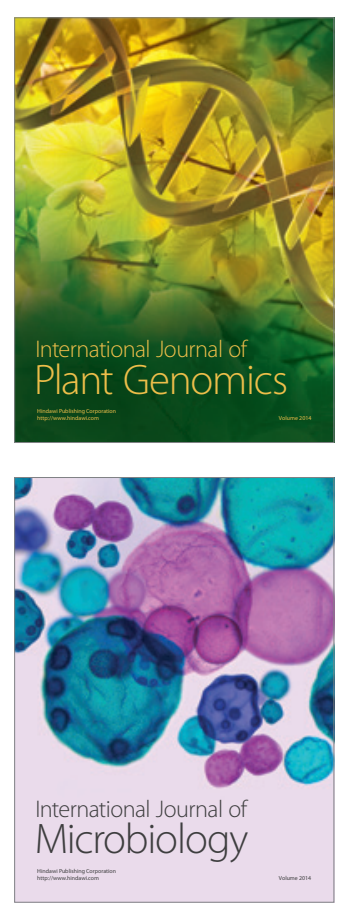

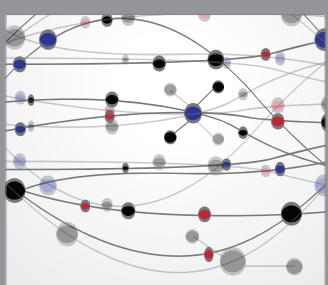

The Scientific World Journal
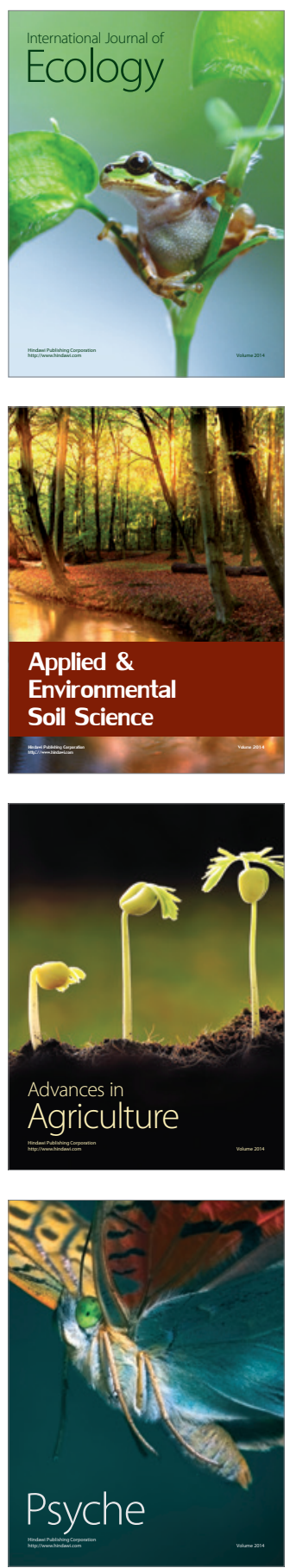